\title{
Māori social workers' experiences of care and protection: A selection of findings
}

\section{Paora Moyle}

Paora Moyle is Ngāti Porou and an independent social work supervisor based in Wellington.

\begin{abstract}
This article explores the challenges faced by seven Māori social workers who are also members of Aotearoa New Zealand Association of Social Workers (ANZASW) working within the child protection system in Aotearoa. Their views on what has improved for Māori whānau around recent legislation changes to family group conferencing (FGC) and newer policy initiatives such as Whānau Ora are examined. The study used a Māori-centred research approach and a thematic analysis of participants' accounts was undertaken. From this analysis it was found that: (a) the participants walked creatively between two world views in order to best meet the needs of their own people; (b) these Māori practitioners felt over-worked and under-valued; and (c) the participants viewed the practices within FGCs as biased, demonstrating a lack of bicultural ability and contributing to significant barriers that whānau Māori experience in care and protection.
\end{abstract}

\section{Introduction}

This article presents a selection of key fi from a study undertaken as partial fulfi of completing a Master of Social Work degree. The study, titled From Family Group Conferencing to Whānau Ora: Māori social workers talk about their experiences, explored the challenges faced by seven very experienced Māori social workers in care and protection. Their views on what has improved for Māori around recent changes to FGC and newer policy initiatives such as Whānau Ora were also examined. Half of the total families who participate in care and protection processes are whānau Māori (MSD, 2010) and a critical factor inhibiting our understanding of this disproportionate participation, is the culture of silence that exists around this issue.

The participants were very experienced Māori social workers who were members of the Aotearoa New Zealand Association of Social Workers (ANZASW), practising in the care and protection sector in a particular region of New Zealand. They were an even spread of being based in Child Youth and Family (CYF), the health sector or community organisations. Consultation with and support for this project was sought from indigenous member groups within ANZASW. The Massey University Human Ethics Committee also approved the project. The chosen methodology was a Māori-centred approach, drawing strongly from Kaupapa Māori theory and principles, using qualitative methods (see the article A model for Māori research for Māori practitioners by Paora Moyle earlier in this issue). Pseudonyms were used to ensure confidentiality. 


\section{Results and discussion}

\section{A lack of Māori practitioners}

One key finding of the study was the various 'in-between' roles Māori practitioners take on when supporting non-Māori practitioners to effect better outcomes for whānau. These roles were teacher, cultural advisor, interpreter and advocate. Whā commented:

We wear both hats ... looking at the system and how Māori social workers balance and bridge opposing world-views. We have to work twice as hard to get the job done.

Ono also commented:

You have to have a heart for the mahi (work) ... you don't have a choice about being the 'in between'... one shares their ability to walk in te ao Māori (Māori world) me te ao Pākehā (non-Māori world).

And more telling is Tahi's comment:

My greatest challenge in social work is ... getting non-Māori to understand where Māori are coming from.

This result aligned with the 'in-between' roles described in studies with Aboriginal and First Nation social workers in Australia and Canada. In these studies, the role and identity of the indigenous social worker is continuously negotiated alongside the professional social work identity that is dominated by Western discourse (Bennett \& Zubrzycki, 2003; Blackstock \& Trocme, 2005). An indigenous practitioner walks the tightrope between two world views whilst at the same time managing their own personal and professional identity. This is an example of dual accountability and as suggested by Love (2002) it is an unenviable position for Māori practitioners. Unlike their non-Māori counterparts they face the double burden of professional and cultural expectations in organisations as well as from communities. Love's (2002) work on FGC best describes this for Māori practitioners in statutory agencies:

Battling a system from within is a role that consumes enormous energy and can limit vision. It can leave the social worker vulnerable to both the organisation and the community. This position leaves Māori workers exposed to being individually demonised and labelled by institutional representatives as incompetent or unprofessional, if we do not conform to institutional mores. On the other hand, Māori workers perceived as conforming to the norms within statutory welfare systems, may be viewed by their whānau, hapū, iwi and communities as brown faces doing the dirty work that was previously done by white social workers $\ldots$ the challenges they face are amplifi and one is over-worked and yet undervalued or worse, invisible (Love, 2002, p. 32).

In other words the Māori practitioners in this study often compensated for the lack of bicultural capability in the care and protection system. This is particularly difficult when they have their own casework to complete as well as providing support to their colleagues. They are often undervalued and ill rewarded for their cultural and professional expertise and this additional responsibility takes a toll on them that goes unrecognised. This finding is consistent with Hollis-English' (2012) where she describes this position for Māori practitioners as 'brown-face burnout:' 
Brown-face burnout has two important components; first it is about Māori social workers being over worked and generally unhappy about their workload. The second ... burnout is associated with their ethnicity, being Māori.

This reference to 'burnout by being Māori' means that burnout is due to cultural expectations and additional responsibilities because of being Māori. This position is also reflected within the findings of the Grassroots Voices Report, which showed a concerning lack of and high turnover of Māori practitioners in the social services. The same report also found that social workers in general needed on-going training and support around working more effectively with whānau (NZCCSS, 2010).

The participants' perspectives revealed that the lack of Māori practitioners in social services and 'sign up from higher up' limited the growth of Māori-appropriate programmes and methods in essential social work with whānau. The scarcity of indigenous programme or method growth is supported by Durst (1998) and Libesman (2004), whose work asserts that a factor inhibiting increased control of indigenous child and family services is the under-representation of indigenous workers. This then perpetuates the challenges that Māori practitioners and whānau face in care and protection because the status quo is maintained.

The toll of the 'in-between' role for Māori practitioners is 'turnout or burnout'. This refers to the high turnover of Māori practitioners through stress and burnout in the sector. Rima commented on the toll it takes on Māori practitioners in CYF:

It's hard, I have to humble myself ... it's quite shameful having to justify the processes to whanau. It is personal because I am the ministry, I am Child Youth \& Family.

The Carr and Peters (1997) review of Native American child protection teams found that permanency should be a critical factor in the choice of indigenous practitioners because high staff turnover brings problems with training, confidentiality, knowledge loss and cohesion. Consequently this leads to stress, mental health issues and burnout for indigenous practitioners. This would also seem to support the HRC (2012) assertion that the under-representation of Māori practitioners in the social services sector or any of the public sectors is a manifestation of structural discrimination. This means, as described by the participants' the 'one world view and one size fits all' dominant mode of social work is maintained, to the detriment of a lack of Māori or bicultural capable practitioners in the sector. The implication of this is that capacity building or Māori advancement within social work is therefore inhibited. For every step forward there is a step backwards as the system maintains its monocultural status quo.

As Tauri (1999) and Love (2000) assert it takes a lot more than just increasing the number of Māori workers in a workforce as this is a grafting of Māori faces and processes onto the same monocultural system, which they describe as merely tokenism. For any social service delivery to be culturally competent it needs to move beyond co-opting Māori practitioners into mainstream programme delivery, and attempt to incorporate indigenous knowledge into the mainstream delivery frameworks (Weaver, 1998; Libesman, 2004; Hollis-English, 2012). The growing of the Māori practitioner workforce needs to be both a strategic development and a shared responsibility. This is needed not only in social services but also in partnership with Māori using structured and sustainable approaches across a wide range of sectors including health, education, justice and research (HRC, 2012). In practice this means 
whānau Māori-specific teams with Māori and non-Māori practitioners working biculturally using Māori practices and methods. This should be in addition to being guided by culturally competent supervisors and supervision practice (O'Donoghue, 2010; Hollis-English, 2012).

The lack of Māori practitioners and culturally competent practice in care and protection is best illustrated when explaining the findings concerning 'patch $\mathcal{E}$ dispatch' and 'not chasing (investigating) a child's whakapapa'. The participants referred to these practice examples the most when describing the challenges they face supporting their non-Māori colleagues to work more effectively with whānau.

\section{The practice of 'patch and dispatch'}

The results showed that the practice of 'patch and dispatch' was a consequence of nonMāori inability to work biculturally and appropriately assess the needs of a whānau Māori. Furthermore, it was a significant contributor to whānau experiencing the revolving care and protection door scenario. Whānau were often only being assessed in terms of their presenting issues and without the social worker 'researching back' into the underlying issues. This researching back would involve looking at past files and case notes in terms of the history of the whānau's social service involvement and finding out what interventions had previously been tried with them. Rima explained this:

Often I'd find more patch jobs happening as opposed to trying to get to the root ... a lot of the job was re-challenging them (non-Māori) on why it is they took a certain approach and unpacking that on a cultural level, or offer up suggestions. The amount of whānau going through FGC is so high ... but does it need to go to FGC? For me it's not actually my role...a lot of whanau have had generational involvement with care and protection ... patch and dispatch is not helpful for them.

In cases where whānau were not being assessed appropriately, they were often referred to a FGC without the opportunity of less informal interventions being explored with them. This is despite Connolly's (2006) assertion that the FGC model is a high-end legal and intrusive intervention and should only be used where there are high levels of risk.

In terms of assessed risk 'patch and dispatch' also occurred when the assessment tools used to assess risk for a whānau were culturally inappropriate, even non-applicable. Ono encapsulated this:

One of the challenges I continue to experience is the way non-Māori assess whanau. Statutory social workers have become desensitised from family-focused social work and now more risk-adverse operators. I was around when the 'Risk Estimation System' ${ }^{1}$ came and it was designed to assess potential risk not actual risk and thus a justification for removing a child ... any imported child risk assessment tool cannot be applied to Māori because it's incapable of assessing the historical root causes of risk for them.

This finding is consistent with Stanley's (2007) work where he asserts that the Risk Estimation System (RES)1 only assessed risk for a child within the realm of direct physical harm. However, the harm caused to a child by separating them from their whānau was

The Risk Estimation System (RES) is based on the Manitoba Risk Estimation System (MRES). The MRES was introduced into social work practice in New Zealand in 1996. 
not recognised as a risk, by either the social worker, the RES tool or indeed the system that supported the use of the tool.

Another finding of 'patch and dispatch' was social workers nursing a predetermined outcome for a whānau and using the FGC process to rubber-stamp that outcome (i.e. uplifting a child). On this Ono said:

If it doesn't happen (agreement) then the power is with them (CYF) and they can close the process or you get a non-agreement.

Rima also commented:

It's more state centred ... they (CYF) would prefer the whānau agreement according to what they $(\mathrm{CYF})$ want and not what the whānau want. If the whānau doesn't come to an agreement then they (CYF) uplift the child anyway.

According to participants, this practice was premised on the mainstream view that a child's needs are paramount and thus viewed as separate from the need to strengthen the whannau. 'Patch and dispatch' practice aligns with the findings of Rimene (1994), Love (2002) and Pakura (2005). They talk about the FGC being used to forward the social worker's agenda rather than it being utilised to determine ways to strengthen the whānau balanced with the child's best interests as the CYP\&F Act 1989 advocates. In particular Rimene (1994, p. 87) found that:

Practitioners manipulated the process to the outcome of what they think was in best interests of a child and used discretionary powers to veto whānau decisions (Rimene, 1994, p. 87).

Maxwell \& Pakura (2006) provide some understanding of this practice when they discussed social workers' mistrust of family during the FGC process and fear of loss of control:

When professionals are cynical or judgemental about the importance or competence of the extended family they often fear losing control in decision-making and consequently family are disenfranchised. Inevitably in such circumstances the family group conference process is likely to fail or there will only be token agreement about outcomes (Maxwell \& Pakura, 2006, p. 4).

This means that when social workers do not trust the ability of the whānau to make competent decisions they may take control of the proceedings or, worse, predetermine the outcome. Ono commented:

What chance does a whānau have deciding what's in the best interests of tamariki, if the FGC outcomes are predetermined?

This finding supports Stanley's (2007) work with social workers, when he found that the majority of them held predetermined ideas about the outcomes they regarded as being in the best interests of a child. He also found that they used the FGC to formalise an ongoing role for CYF and the level of intervention they saw as necessary to ensure a child's safety. Social workers described using the FGC as an increased intervention step and as a way to formalise monitoring of families. For other social workers he interviewed, the FGC provided the mandate to formalise support plans around families (i.e. going for declaration/ custody order) (Stanley, 2007). 'Patch and dispatch' is an example of bias practice and ethnic 
inequality for whānau Māori in care and protection. This would also suggest that the FGC is more useful as an example of fiscal control or as a state-centred process rather than as a family-centred process.

Overall, the Māori practitioners' perspectives suggest that the FGC is being used as a state-centred tool rather than a whānau-centred (or led) decision-making process. Furthermore, it indicates that care and protection social workers are focusing on the child and not balancing this with the strengthening of the whānau. In other words, they are not working with the decisions of the whānau to better enable the needs of the child to be met or maintained within its whānau. This is not suggesting that Māori children should remain in abusive situations but instead that they should (wherever possible) live with or know who their whānau are and have regular contact with them. This leads onto the second practice example that participants most referred to when describing their support of non-Māori practitioners to work more effectively with whānau, which is 'not chasing (investigating) a child's whakapapa.'

\section{Not investigating a child's whakapapa}

The results concerning the centrality of a child's whakapapa and place within its whānau as fundamental to their long-term wellbeing found that the practice of investigating a child's whakapapa was commonly being overlooked in care and protection. Ono described this:

When you are dealing with whanau Māori you have to have workers who are not afraid of Māori and who know how to investigate the whakapapa of a child. If not, then you have to have culturally competent supervisors and managers on board who do ... this is not currently the case in care and protection ... Basically, they do not know how to chase the whakapapa of a child ... it's the 'too hard basket.'

The reasons for this may be varied, but lamentably the Māori practitioners' views lead one to conclude that where there are no bicultural-capable practitioners, Māori children are being transacted through the system without their whakapapa in tow. This would mean little or no whānau support, which aligns with Rimene's (1994) review of the CYP\&F Act where she stated:

To work with Māori people you have to be able to access them. This means knowing how to contact them, knowing the relationships between the members ... And knowing how to whakapapa into their respective whānau, hapū and iwi (Rimene, 1994, p. 72).

Rimene determined that practitioners who were largely Pākehā and middle class were incapable of networking with whānau, hapū and iwi at the time. Later when CYPFS were developing a data system that captured the ethnicity of a child, Kuni-Shepard (1997) researched non-Māori social workers working with whānau. He found that they were not recording the whānau, hapū and iwi details of Māori children coming to notice, despite the system being capable of capturing that information. Instead, non-Māori practitioners were choosing not to seek the whakapapa information of Māori children because it was too difficult, regardless of the Act requiring them to do so. A critical consequence of this was that essential whānau were not invited to the FGC (Pakura, 2005). This is in stark contrast to Pakura's later assertion in the same paper that the Crown's recognition of whakapapa as central to the identity of our indigenous people was a success. 
Although this research was limited to the lower North Island region and the researcher could not quantify the practice of 'not investigating a child's whakapapa,' the fact that experienced Māori practitioners testified to it happening is incomprehensible. If social workers are not trained and encouraged to value whakapapa and held to account for this essential mahi then culturally incompetent practice will very likely continue.

Whakapapa was important to the participants for many reasons, as arguably the first claim to being Māori is through whakapapa. It is not the percentage of Māori blood a person possesses; it is their history, their connection to their past and future investment for whānau, hapu and iwi. In this sense whakapapa is not only identity; it is a duty and an obligation that Māori have to be able to effect. Understanding and knowing one's whakapapa is crucial in terms of Māori cultural identity and without this knowledge Māori may not lead full and meaningful lives. Through whakapapa an individual or group cultural identity is affirmed. Tamariki and rangatahi are taonga and their whakapapa completes them through affirming that they come from thousands of their tūpuna. It links them with their history, citizenship, cultural identity and sovereignty (Jackson, 1988; Rimene, 1994; Moyle, 1998).

The importance of whakapapa for a child is well documented and publicised in mainstream literature so it is not a new or difficult concept for social workers working with whānau Māori. What is not publicised and is unacceptable is that investigating a child's whakapapa is essential social work that is often is not happening for tamariki subject to care and protection involvement. Even after 23 years of changes to improve the over-representation of Mãori in the welfare system, findings align with the literature to show that nothing of consequence has really improved for them. This also has implications for members of ANZASW and the SWRB, both of which expect a level of cultural competency when working with whānau Māori. It is clear that the standard is not high enough and that some social workers know how to 'say' they can build whakapapa connections but don't actually do it. This raises the notion that they might lack the skills to do the mahi or actually consciously choose not to, even though they know they should.

According to the findings, social workers who don't know how to chase the whakapapa of a child need to be supported to see Māori as much greater than the 'too hard basket.' They also need to have a genuine desire to improve outcomes for them, otherwise Mãori will continue to be perceived as a resented minority, an endless defi and 'fi drain on hard working taxpayers' (HRC, 2012). It is not the responsibility of Māori practitioners to compensate for the lack of culturally competent practice in care and protection (Hollis, 2006). Organisations and leaders in the sector need to actively support Māori practitioners to become professionally registered and to enable them to utilise their own world views and tikanga Māori methods (Hollis-English, 2012). Māori practitioners also need to be employed as supervisors and supported to provide Kaupapa Māori, cultural or cross-cultural supervision to all frontline social workers (O'Donoghue, 2003). When social workers are supported to develop greater awareness of their own attitudes towards those who are culturally diff ent from themselves the result is improved outcomes for whānau (Eruera, 2005). This includes their ability to ask the question: 'If they are fearful and/or untrusting of Māori are they best placed to be working with Mãori?' (Libesman, 2004). This would also develop greater indigenous human rights awareness and cultural competence in practitioners. 


\section{Indigenous rights and cultural competence}

The findings regarding 'patch and dispatch' and of 'not investigating a child's whakapapa' have implications in terms of meeting rather than contravening the principles of Te Tìriti ō Waitangi, the CYP\&F Act, the United Nations Convention on the Rights of the Child (UNCROC) and United Nations Declaration on the Rights of Indigenous People (UNDRIP). It is worth referring to the most recent HRC (2012) document titled, 'Inquiry into the determinants of wellbeing for Māori children'. This document reiterates the principles of Te Tìriti that whānau Māori have the right to:

(a) Enjoyment of all their rights on an equal basis as other children (Te Tīriti, article 3; UNCROC, article 2; UNDRIP articles 1, 2, 21)

(b) Live as Māori, including the right to te reo, and te ao Māori (Te Tīriti, article 2; UNCROC, article 30; UNDRIP, articles 5, 9 and 11-15) (see HRC, 2012b: 17).

According to this document, the Crown has obligations to protect these indigenous rights and the standards indicate that government investment (present and future) should address inequalities experienced by Māori (HRC, 2012). This includes acknowledging that biased practices occur in care and protection just as it does in any other area of service provision. Whether it's intentional or accepted there is a growing body of literature particularly in health that provides consistent evidence that frontline practitioners do treat people diff ently based on ethnicity (see for example, Reid, 2000; Crengle, Lay-Yee, Davis, \& Pearson, 2006; Jansen, 2011).

Although ethnic inequality in Aotearoa is entrenched and social and economic factors contribute to and compound these inequalities, these factors alone do not cause inequalities, they are also fed by bias practices (HRC, 2012). Tauri (2010) asserts that biased practice completely misses the social and economic benefits of diversity. An example of this would be taking full advantage of a child's whakapapa and the social and economic benefit of whānau being involved in the long-term care of that child. However, given the above findings a big question and a topic worthy of further research is: What is cultural competency in Aotearoa? Do our social work tertiary institutions in Aotearoa need to review their teaching curriculum? Equally, do our professional/registration bodies need to review their process for approving the 'cultural competency' of practitioners?

The results from this study found that the inequality that Māori practitioners and whānau experience in care and protection is born from ethnocentric (Pākehā as superior) monoculturalism (the one 'right' culture). These are powerful and ingrained characteristics of a 'one-world' view and 'one-size fits all' culture. These characteristics cannot be seen but are very real concepts that operate outside the level of individual or collective conscious awareness, and therefore are harmful to Māori (Jackson, 1988, Rimene, 1994; Love, 2002; Tauri, 2010; Tauri, 2012). Both concepts define the reality of structural discrimination that advantages non-Māori whilst disadvantaging Māori (HRC, 2012). Although most social workers believe in equality and diversity, the inability to deconstruct these two concepts allows practitioners and organisations to continue implementing policies and practices that disadvantage whānau Māori.

\section{Conclusion}

This article presented a selection of key fi from a study undertaken as partial fulfi of completing a Master of Social Work degree. The study found that (a) the participants cre- 
atively walked between two world views in order to best meet the needs of their own people; (b) these Māori practitioners felt over-worked and under-valued; and (c) the participants viewed the practices within FGCs as biased, demonstrating a lack of bicultural ability and contributing to significant barriers that whānau Māori experience in care and protection.

There is little bicultural capability that exists in care and protection and this leads to Māori being misunderstood and treated diff ently than non-Māori based on ethnicity. This was particularly evidenced through what participants described as the practice of 'patch and dispatch' and 'not investigating a child's whakapapa'. The study also showed that Māori social workers practised inside the mainstream mode of 'one world view and one-size fi all'. This often made them invisible and/or isolated inside organisations and occurred without suffi Māori supervision, leadership and cultural support. This resulted in high turnover of Māori practitioners, knowledge loss, work overload and burnout in the care and protection sector. In addition to this, the Māori experience of FGC and related care and protection processes are being ignored by generalising them into the mainstream mix of research, ministerial reports and programme evaluations. Further research on the key fi raised in this study is required and only research that directly engages with Māori will provide authentic and valid fi towards improved care and protection practice for them.

\section{References}

Bennett, B., \& Zubrzycki, J. (2003). Hearing the stories of Australian Aboriginal and Torres Strait Islander social workers: Challenging and educating the system. Australian Social Work, 56(1), 1-78.

Blackstock, C., \& Trocme, N. (2005). Community-based child welfare for Aboriginal children: Supporting resilience through structural change. Social Policy Journal of New Zealand, 24(1), 12-33.

Carr, J., \& Peters, M. (1997). Assessment of multi-disciplinary child protective teams in five Western Washington communities: Chehalis, Nisqually, Shoalwater Bay, Skokomish, Squaxin Island. (Unpublished MPA thesis). Evergreen State College, Washington, United States.

Connolly, M. (2006). Fifteen years of family group conferencing: Coordinators talk about their experiences in Aotearoa New Zealand. British Journal of Social Work, 36(4), 523-540.

Crengle, S., Lay-Yee R., Davis, P., \& Pearson, J. (2006). Comparison of Māori and non-Māori patient visits to doctors. National Primary Medical Care Survey, Report 6. Retrieved from: http://www.moh.govt.nz/notebook/nbbooks. nsf/0/D222772D6D01D0FACC25748C007D64D8/\$file/NatMedCaReport6Dec2005.pdf.

Durst, D. (1998). The wellness of Canadian first nations children: Seeking solutions through self government. Unpublished draft research paper. Retrieved from http://www.snaicc.org.au/_uploads/rsfil/02785.pdf.

Eruera, M. (2005). He Korero Korari. Supervision for Māori: Weaving the past, into the present for the future. (Unpublished doctoral dissertation). Massey University, Palmerston North, New Zealand.

Hollis, A. (2006). Pūao-te-ata-tū and Māori social work methods. (Unpublished master's thesis). University of Otago, Dunedin, New Zealand.

Hollis-English, A. (2012). Māori social workers: Experiences within social service organisations. A thesis submitted for the degree of Doctor of Philosophy. University of Otago, Dunedin, New Zealand.

Human Rights Commission. (2012). Inquiry into the determinants of wellbeing for Māori children. Submission to the Māori Aff Select Committee. Retrieved from: http://www.hrc.co.nz/2012/Māori-children-denied-basic-human-rights.

Jackson, M. (1988). Māori and the criminal justice system: He Whaipaanga Hou: A new perspective (Parts I \& II). Wellington: Department of Justice.

Jansen, P., \& Jansen, D. (2011). Māori and health. In Cole's Medical Practice in New Zealand, pp.48-60 (p.53). Retrieved from: http:/ / www.mcnz.org.nz/assets/News-and Publications/Coles/Chapter-5.pdf.

Kuni-Shepherd, O. (1997). The policy and practice of recording iwi affiliation. Social Work Now, 6, 12-16. Retrieved from: http://www.cyf.govt.nz/about-us/publications/social-work-now.html.

Libesman, T. (2004). Child welfare approaches for Indigenous communities: International perspectives. National Child Protection Clearing House, 20, 1-39. Retrieved from: www.aifs.gov.au/nch/pubs/issues/issues20/issues20.html.

Love, C. (2000). Family group conferencing: Cultural origins, sharing and appropriation - a Māori reflection. In G. Burford, \& J. Hudson (Eds). Family group conferencing: New directions in child and family practice. New York; Walter de Gruyter.

Love, C. (2002). Māori perspectives on collaboration and colonisation in contemporary Aotearoa/New Zealand child and family welfare policies and practices. Partnerships for Children and Families Project. Wilfred Laurier University, Ontario, Canada. 
Maxwell, G. \& Pakura, S. (2006). The Family Group Conference: Does it work for child protection? Presentation for the study tour: A Restorative Justice System for Juveniles: Information for Mexico from New Zealand. Retrieved from: http://igps.victoria.ac.nz/events/completed-activities/RJ\%20Mexico/CareProtFGC.pdf.

Ministry of Social Development. (2010). The statistical report. Retrieved from: http://statistical-report-2010.msd. govt.nz/.

Moyle, P. (1998). Walking the talk: A record of Crawford whakapapa and selected stories from Ngati Porou. Unpublished Research Report, Victoria University of Wellington.

New Zealand Council of Christian Social Services. (2010). Grassroots voices: The voice of New Zealand families and communities. Retrieved from: http://www.justiceandcompassion.org.nz/site/home.php.

O'Donoghue, K. (2010). Towards the construction of social work supervision in Aotearoa New Zealand: A study of the perspectives of social work practitioners and supervisors. (Unpublished doctoral dissertation). Massey University, Palmerston North, New Zealand.

Pakura, S. (2005). The family group conference 14-year journey: Celebrating the successes, learning the lessons, embracing the challenges. Paper presented at the American Humane Association's Family Group Decision Making Conference and Skills-Building Institute, 6-9 June 2004, in Harrisburg, Pennsylvania, USA. Retrieved from: http:/ / www. iirp.edu/pdf/au05_pakura.pdf.

Reid, P., Robson, B., \& Jones, C. P. (2000). Disparities in health: common myths and uncommon truths. Pacific Health Dialog, 7(1), 38-47.

Rimene, S. (1994). The Children Young Persons and their Families Act 1989: From a Māori perspective. Unpublished master's thesis. Victoria University of Wellington. Wellington, New Zealand.

Stanley, T. (2007). Risky work: Child protection practice. Social Policy Journal of New Zealand Te Puna Whakaaro. Retrieved from: http://www.msd.govt.nz/about-msd-and-our-work/publications-resources/journals-and-magazines/social-policy-journal/index.html.

Tauri, J. (1999). Family Group Conferencing: The myth of Indigenous empowerment in New Zealand. Retrieved from: www.usask.ca/nativelaw/publications/jah/.../Fam_Grp_Conf_NZ.pdf.

Tauri, J. (2010). Indigenous perspectives and experiences: Māori and the criminal justice system. Retrieved from: http:/ / www.sfu.ca/ palys/Tauri \%20chapter\%20on \%20Māori\%20the\%20CJS.pdf.

Tauri, J. (2012). The indigenous criminologist. Retrieved from: http://juantauri.blogspot.co.nz/2012/03/media-politics-and-darkies-behaving.html.

Weaver, H. (1998). Indigenous people in a multicultural society: Unique issues for human services. Social Work, 43(3), 203-211. 